\title{
The epithelial to mesenchymal transition (EMT) and cancer stem cells: implication for treatment resistance in pancreatic cancer
}

\author{
Pingting Zhou' ${ }^{1 \dagger}$, Bo Li ${ }^{2 \dagger}$, Furao Liu', Meichao Zhang ${ }^{1}$, Qian Wang ${ }^{1}$, Yuanhua Liu ${ }^{3}$, Yuan $\mathrm{Yao}^{4}$ and Dong Li ${ }^{*}$
}

\begin{abstract}
The mechanical properties of epithelial to mesenchymal transition (EMT) and a pancreatic cancer subpopulation with stem cell properties have been increasingly recognized as potent modulators of the effective of therapy. In particular, pancreatic cancer stem cells (PCSCs) are functionally important during tumor relapse and therapy resistance. In this review we have surveyed recent advances in the role of EMT and PCSCs in tumor progression, metastasis and treatment resistance, and the mechanisms of integrated with biochemical signals and the underlying pathways involved in treatment resistance of pancreatic cancer. These findings highlight the importance of confirming stem-cells markers and complex molecular signaling pathways controlling EMT and cancer stem cells in pancreatic cancer during tumor formation, progression, and response to therapy.
\end{abstract}

Keywords: Pancreatic cancer, Cancer stem cell, Epithelial-to-mesenchymal transition, Resistance

\section{Background}

Pancreatic cancer (PC) is one of the poorest prognosis malignancies with a 5-year survival rate of less than $5 \%$ and a median survival of no more than 6 months after diagnosis [1, 2]. Even among patients diagnosed with early-stage disease who undergo clean surgical margins resection (R0 resection) followed by adjuvant chemotherapy, the median survival rate is approximately 2 years, with a 5-year survival of $15-20 \%$ [3-5]. This devastating situation is due to several factors. First, due to the absence of effective tools for an early detection, most patients at the time of diagnose have locally advanced or metastatic disease, and lose the opportunity of surgical resection. Second, even for those patients who undergo surgical resection, the prognosis is poor due to early relapse and distant metastasis. Metastasis is a characteristic of pancreatic cancer and the leading cause of mortality among cancer patients [6]. Finally, PC shows profound resistance to relative chemotherapy and radiation treatment. Cancer cells resistant to treatment usually show more aggressive,

\footnotetext{
* Correspondence: lidong@shsmu.edu.cn

${ }^{\dagger}$ Equal contributors

${ }^{1}$ Department of Oncology, Shanghai Ninth People's Hospital, Shanghai

Jiaotong University School of Medicine, Shanghai, China

Full list of author information is available at the end of the article
}

such as accelerated metastasis to distant organs and tissues. Thus treatment resistance becomes the major challenge in clinical cancer therapies. The focus on the management of PC patients, especially those in advanced stages, is to understand the pathophysiological mechanisms of therapy resistance and overcome the resistance.

Cellular heterogeneity is a well-recognized property of both normal and malignant tissues. The difference is that heterogeneity in the normal tissues is an ordered developmental program. However, tumors are composed of a small set of distinct cells termed cancer stem cells (CSCs), which is capable of driving tumor initiation and development. The CSCs model, on the other hand, suggests that the biology process of the tumor is driven by a small population of cells with the stem cell properties of sustaining growth and an ability to differentiate into the entire heterogeneous tumor [7]. Dick and colleagues in 1997 identified the first cancer stem cell in hematopoietic malignancies, such as acute myelogenous leukemia and chronic myelogenous leukemia using cell surface marker expression [8, 9]. Hematopoietic stem cells (HSCs) can self-renew and differentiate into all the cells of the hematopoietic system, and are responsible for lifelong blood production [10]. After the discovery of CSCs in leukemias, the first CSCs in solid tumors were 
identified in breast tumors [11], leading to much research in a variety of tumors, including glioblastoma [12], pancreas [13, 14], melanoma [15], prostate [16] and colon [17]. PCSCs have been first discovered in 2007 and since then have conducted as a subpopulation of cancer cells with special functional features including self-renewal and exclusive in vivo tumorigenicity. Furthermore, the resistance of PC to standard chemotherapy and radiation treatment may in part be due to the existence of CSCs, which can express multidrugresistant membrane transporters, aberrantly activate proliferation signaling pathways and increase the capability of repairing DNA.

Although there are a growing number of studies that support the CSCs model in cancer, diverging theories exist on the precise origin of cancer stem cells. It is not yet known whether they originate from the tissue's normal stem cells by the accumulation mutations or the acquisition of the mutations in more-differentiated cells. Recent studies have implicated that the process termed epithelial-to-mesenchymal transition (EMT) is associated with features of CSCs $[18,19]$. This review focuses on recent research findings related the role of EMT and CSCs on chemotherapy and radiotherapy resistance in pancreatic cancer, helping understand the complex biology of treatment resistance for the more effective treatments for PC patients.

\section{EMT in cancer}

In addition to the field of EMT in normal embryonic development, there are numbers of new work on the role of EMT in tissue fibrosis and cancer metastasis [20-22]. In March 2008, at a Cold Spring Harbor Laboratory meeting about EMT, the scientists classified EMT into three general subtypes based simply on the different functional consequences [23]. Type 1 EMT can generate mesenchymal cells (primary mesenchyme) that have the potential to generate secondary epithelia by mesenchymal-epithelial transition (MET), which is associated with embryonic gastrulation and neuroepithelial giving rise to monile neural crest cells. Type 2 EMT is associated with wound healing, tissue regeneration, and organ fibrosis, which are in essence an unabated form of wound healing in response to persistent inflammation. Type 3 EMTs occur in epithelial neoplastic cells undergoing genetic and epigenetic changes, producing outcomes far from those observed in other two types EMT. Neoplastic cells undergoing type 3 EMT may migrate through the blood stream and generate secondary nodules, threatening manifestations of cancer progression. It is now widely accepted that in epithelial cancers, including pancreatic cancer, EMT is associated with the three major steps of cancer development: invasion, dissemination and metastasis $[24,25]$. While the reverse process, a mesenchymal to epithelial transition
(MET), is believed to support metastatic progress once migratory cells have reached their destination [26, 27]. During EMT, cells lose their epithelial cell-cell adherens junction and apical-basal cell polarity and acquire mesenchymal characteristics with spindle-like cell shape and with the ability to migrate [28].

A variety of markers have been used to demonstrate EMT. E-cadherin, intergrins, and cytokeratins are the most commonly used epithelial markers and $\mathrm{N}$-cadherin, vimentin or fibronectin for the mesenchymal [26]. In recent years, the cadherin switch from E-cadherin to $\mathrm{N}$ cadherin, have been increasingly used to monitor EMT during cancer development. However, cells do not gain mesenchymal traits in a partial EMT. Early EMT might only involve loss of E-cadherin and do not gain $\mathrm{N}$ cadherin, this phenomenon may lead to different biological results of the intermediate states and likely behave distinctly during migration and invasion to those that do gain N-cadherin $[29,30]$. Hence, it is important to consider not only epithelial or mesenchymal traits during EMT but also other processes related to EMT, such as invasion, increased survival or decreased proliferation.

EMT change is triggered in a number of distinct molecular processes including the expression of specific cell-surface proteins and the activation of transcription factors (TFs). The list of potent EMT-inducing transcription factors (EMT-TFs) has been growing ever since [31], EMT-TFs belong to different families, including superfamily, SNAI1 (previously known as Snail) and SNAI2 (previously known as Slug), two ZEB factors, ZEB1 (also known as dEF1/TCF8) and ZEB2and Twist. Other TFs have been shown to be related with EMT, including Prrx1,Sox4 and Sox9 [32, 33], Klf4 [34] and members of the AP-1 (Jun/Fos) family [35]. It is reported that EMT-TFs have been involved not only in migration and invasion but also in the protection from senescence and apoptosis, regulation of cell progression and resistance to chemotherapy and radiotherapy [36-38]. These EMT regulators have been shown to repress the expression of E-cadherin [39-42] through binding to conserved E-box sequences (mainly of the CAGGTG type) in the promoter of E-cadherin $[41,43]$. Loss of E-cadherin can drive certain epithelial cells toward a mesenchymal state [44].

EMT associated with tumors can be induced by various secreted factors from the stroma, such as transforming growth factor beta (TGF- $\beta$ ), hepatocyte growth factor (HGF) and platelet-derived growth factor (PDGF). Among these, TGF- $\beta$ has received substantial attention as a major inducer of EMT during embryogenesis development, cancer progression and fibrosis. Consequently, TGF- $\beta$-induced EMT has been better understood than EMT in response to other inducers. In response to TGF- 
$\beta$-ligand binding, TGF- $\beta$ receptors I and II (TGF- $\beta$ RI/ TGF-BRII) which have a serine/threonine kinase activity lead to phosphorylation of Smad2 and Smad3, members of the Smad protein family [45]. After the phosphorylation, a Smad signaling cascade is activated, resulting in nuclear translocation of Smad4, which drives a wide range of tumor-promoting factor genes transcription [46]. TGF- $\beta$ additionally induces Smad-independent signaling. Among the non-Smad signaling responses, TGF- $\beta$ can regulate EMT through the activation of Rho GTPases, MAP kinase (MAPK) pathways and the PI3 kinase-Akt-mTOR pathway $[47,48]$. On the other hand, non-Smad signaling can impact the activation of Smad signaling in TGF- $\beta$ induced EMT. For example, Akt activation can sequester Smad3 through unphosphorylated Smad3, impacts Smad activation in response to TGF- $\beta$ in EMT [49]. P38 MAPK cooperates with Smad3/4 in TGF- $\beta$ associated EMT through the transcription factor ATF2 [50]. TGF- $\beta$ can interact with other growth factors such as the epidermal growth factor (EGF) to influence the malignant transformation of CSCs as well as the activation of cancer-associated stromal fibrosis [51-58].

While transcriptional regulation of EMT has been extensively studied, post-transcriptional, translational and post-translational regulators are recently appreciated in several studies $[59,60]$. The number of miRNAs that has been reported to be associated with EMT and MET is becoming as extensive as the list of EMT-TFs [61]. There is no doubt that one of the most concern is the miR-200 family, which has five members classified in to two groups; miR-200a, miR-200b and miR-429 on human chromosome 1, miR-200c and miR-141 on human chromosome 12 [62]. Their low expression of individual family members results in EMT progression by enhancing levels of EMT-TFs Zeb1 and Zeb2, which blocks EMT or induces MET [63]. Conversely, Zeb1/2 directly binding to miR-200 promoters can repress the expression of miRNAs. This interaction between Zeb1/2 and miR-200 family members not only determines cell morphology but also controls cell migration and invasion $[64,65]$. Reversely, microRNA array analyses have suggested that members of miR-200 family were markedly downregulated in TGF- $\beta$-induced EMT and in cancer cell lines displaying an EMT phenotype $[63,66]$. In addition to the members of the miR200 family, miR-10b, miR-373, and miR-520c also play roles in the progression of cancer $[67,68]$. It's reported that miR-21 is enhanced during the process of TGF $\beta$-induced EMT [69]. The details of the interaction of all these factors with each other are stated in Fig. 1.

\section{Pancreatic cancer stem cells}

The hypothesis of PCSCs has been hotly controversial for many years. A new understanding of PC progression

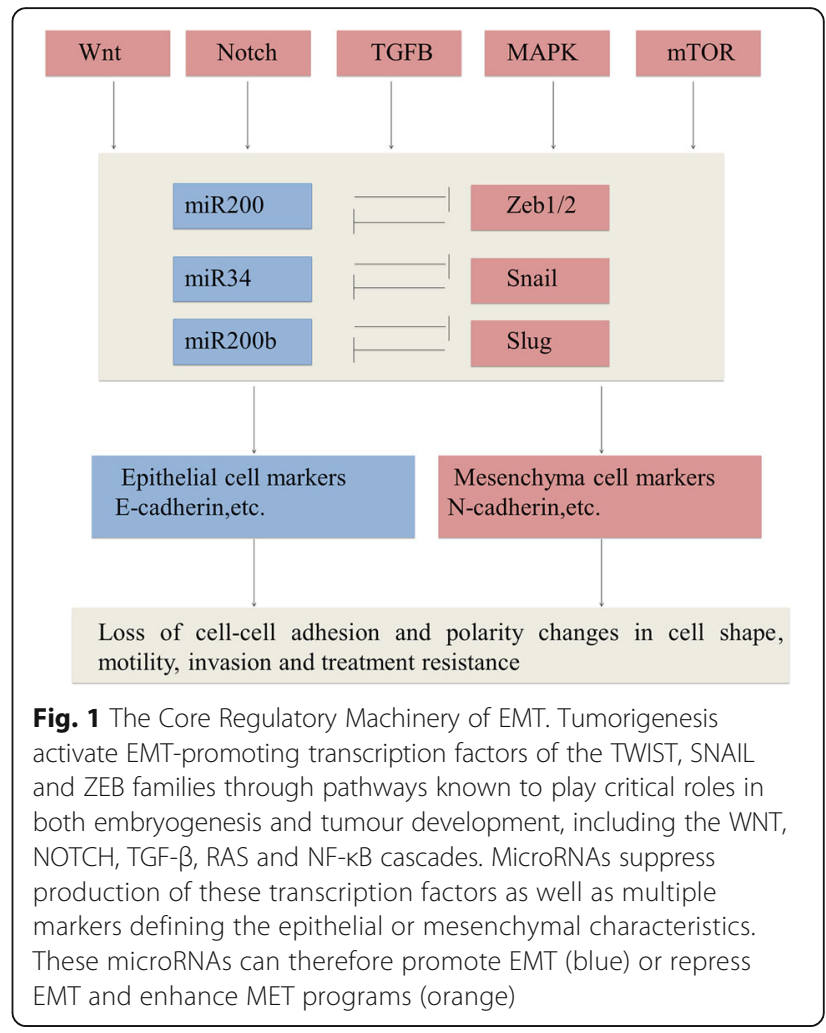

and recurrence has led to the theory that tumorigenesis was facilitated by a distinct population of cancer cells with the properties of stem cells (Fig. 2) [70]. The presence of CSCs has been studied in a variety of hematopoietic and solid organ malignancies $[8,11]$. The current consensus agreement describes that CSCs identified based on specific cell-surface markers are able to self-renew and differentiate into the heterogeneous of cancer cells that comprise the tumor [71]. Opinions on the precise origin of cancer stem cells existed different. One theory is that CSCs originate from the accumulation mutations occurring in normal stem cells and these mutations ultimately trigger a malignant transformation. Alternatively, some studies show that mutations in more-differentiated cells may develop the capacity for unregulated self-renewal and with stem cell-like properties [72, 73]. Hence, the term CSCs, does not indicate the origin of cancer cells, but to the cells that maintain the tumorigenesis $[71,74]$.

In 1997, the first CSC was isolated in myeloid leukemia using cell surface marker expression [8]. Isolating CSCs in solid organs was based on studies in hematopoietic malignancies. However, cell surface markers used to identify CSCs in epithelial solid organ were distinct from those of leukemia CSCs. In PC, CSCs have initially been identified by being characterized as $\mathrm{CD} 44^{+} \mathrm{CD} 24^{+} \mathrm{ESA}^{+}$cells and having the ability to form tumors at a much higher frequency than the bulk tumor 


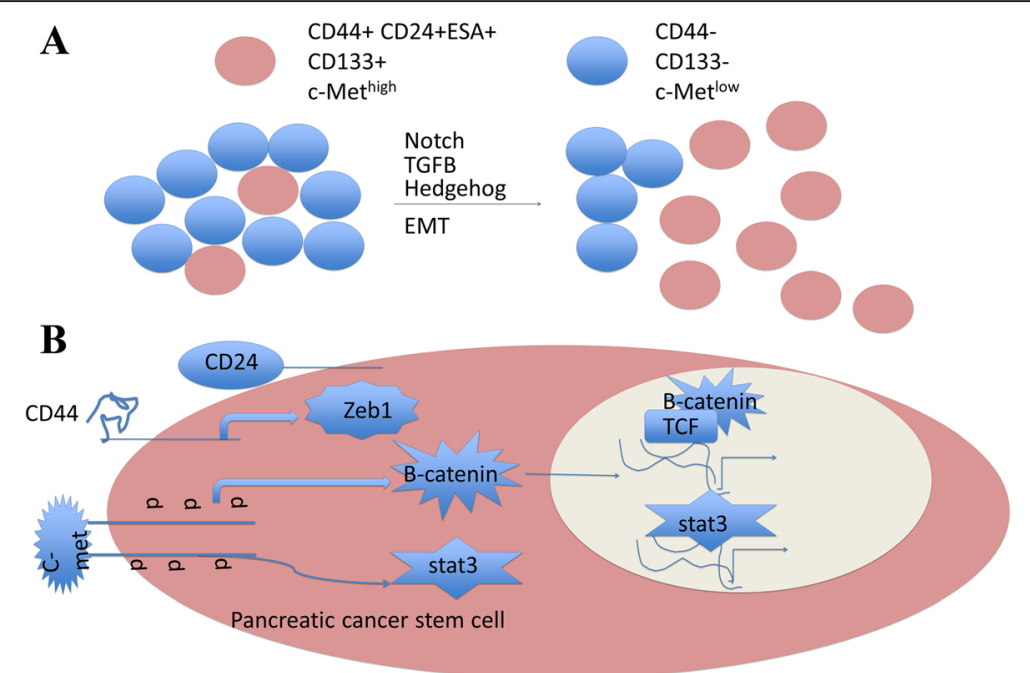

Fig. 2 Contribution of EMT and related signaling to PCSCS. a PCSCs with tumor-initiating capability can be identified by the expression of a distinct set of marker proteins, such as CD44, CD24, CD133 or c-Met. These CSCs can self-renew and differentiate into a number of cell types to generate the heterogeneity of the originating tumor. Inducers of EMT such as TGF- $\beta$, HH or Notch cause cells to acquire a CD44+ CD24 + ESA+ phenotype, reminiscent of PCSCs. b The PCSC cell surface markers CD24, and CD44 likely promote cell-cell interactions, the c-Met respond to secreted ligands to active developmental pathways, such as $\beta$-catenin, Notch and Stat3 in PCSCs. These pathways stimulate the expression of genes that regulate stem-cell properties, such as self-renewal

[13]. The $\mathrm{CD} 44^{+} \mathrm{CD} 24^{+} \mathrm{ESA}^{+}$cells as a reflection of stemness is generally confirmed with the fact that cells enriched for $\mathrm{CD} 44^{+} \mathrm{CD} 24^{+} \mathrm{ESA}^{+}$were far more tumorigenical than other tumor cells. Half of the mice injected with $100 \mathrm{CD}_{4} 4^{+} \mathrm{CD} 24^{+} \mathrm{ESA}^{+}$cells formed tumors, compared with 10000 triple-negative cells, which only 1 in 12 mice developed a tumor. In addition, the tumors formed by the CD $44^{+} \mathrm{CD} 24^{+} \mathrm{ESA}^{+}$cells had morphological features similar to those of the original pancreatic ductal adenocarcinoma from patients. These supporting data pointed that a population of cells are responsible for tumor initiation and self-renewal.

In another group, CD133 was used to identify CSCs from human primary PC samples and PC cell lines [14]. Like CD $44^{+} \mathrm{CD}_{24}{ }^{+} \mathrm{ESA}^{+}$cells, $500 \mathrm{CD} 133^{+} \mathrm{PC}$ cells generated visible tumors that histologically indistinguishable from the primary tumor. In contrast, $10^{6} \mathrm{CD} 133^{-} \mathrm{PC}$ cells failed to induce tumor formation. By flow cytometry analysis, they showed that $\mathrm{CD} 133^{+}$cells and $\mathrm{CD} 44$ ${ }^{+} \mathrm{CD} 24^{+} \mathrm{ESA}^{+}$cells are not identical but have a $14 \%$ overlap. Further experiments will need to estimate the tumorigenic potential of this quadruple-positive subset. This study also investigated the role of pancreatic CSCs in metastasis and the results revealed that a subpopulation of $\mathrm{CD}_{133^{+}}$cells that co-express CXCR4 determined the metastatic ability of PC cells. CXCR4 is a chemokine receptor of the ligand stromal cell-derived factor 1 (SDF1), which is reported to be a mediator of tumor invasion and metastasis [75]. Hermann et al. showed that two groups of mice injected $\mathrm{CD} 133^{+} \mathrm{CXCR}^{+}$and $\mathrm{CD}_{133^{+}}$CXCR4 $^{-}$cells appeared similar tumor development in the early stage, but followed with liver metastases or no any trace of metastases 2 weeks later in $\mathrm{CXCR}^{+}$group and CXCR4 ${ }^{-}$group respectively [14]. The difference in cell populations was activation of CXCR4. These cells, CD133 ${ }^{+} \mathrm{CXCR} 4^{+}$, were noted to have increased in vitro migratory ability and were able to produce metastasis, however $\mathrm{CD}_{13} 3^{+} \mathrm{CXCR} 4^{-}$did not produce distant metastases. Importantly, CXCR4 inhibition prevented tumor metastasis in mice. These findings may have clinical implications that CXCR4 might be a potential target for therapies to inhibit metastasis of PCSCs.

After the identification of $\mathrm{CD} 44^{+} \mathrm{CD} 24^{+} \mathrm{ESA}^{+}$cells and $\mathrm{CD}_{133^{+}}$cells as a population of PCSCs, Li et al. identified c-Met as a hunman pancreatic CSC marker [76]. c-Met, a member of the receptor tyrosine kinase for hepatocyte growth factor (HGF), has an important role in both normal and malignant development [77]. It was shown to be related with tumorigenesis and drug resistance through activating mutations of pathway components or HGF-dependent autocrine/paracrine in tumor development $[78,79]$. They found that c-Met high cells had enhanced tumorigenic potential, whereas c-Met-negative cells did not. They compared the tumorigenicity of different sets of primary tumor cells and identified that c-Met high cancer cell population had the highest tumorigenic potential, compared with pancreatic cancer cells expressing CD44, CD24, ESA and CD133 [76]. Cabozantinib, the c-Met inhibitor, significantly inhibited tumor sphere formation, reduced the population of PCSCs and slowed 
tumor growth. Additional studies have shown that ALDH1 (aldehyde dehydrogenase 1) and Dclk1 (doublecortin and $\mathrm{Ca} 2 /$ calmodulin-dependent kinase-like 1) high cells have enhanced sphere-forming ability, suggesting a propensity to be associated with PCSCs function [80].

Several markers have been defined to discriminate PCSCs, but the signaling pathways that regulate these PCSC functions have not been fully studied. Notch signaling is an important regulator of self-renewal and differentiation in the normal and development pancreas, but the dysregulation of the Notch pathway will lead to uncontrolled self-renewal of CSCs [81-84]. In PC, inhibition of the Notch pathway by either knockdown of the Notch ligand Jagged-1 or blocking Notch pathway with inhibitor MRK-003 leads to reduction of tumor sphere formation $[85,86]$. On the other hand, the activation of Notch pathway acts to maintain the pancreatic precursor state. These findings indicate that Notch signaling is needed for PCSC function [87]. Nodal and Activin belong to the TGF- $\beta$ superfamily and they were shown to be important for human embryonic stem cell maintenance $[88,89]$. In pancreatic cancer, Nodal/Activin is strongly expressed in PCSCs. The Nodal/Activin pathway can affect the self-renewal capacity and stemness properties of pancreatic CSCs and promote invasion of PCSCs [90]. Several studies have identified other developmental pathways such as mTOR, hedgehog for targeting PCSCs [91, 92]. Compared with normal pancreatic epithelial cells, the expression of $\mathrm{HH}$ transcript was increased 46 -fold in $\mathrm{CD} 44^{+} \mathrm{CD} 24^{+} \mathrm{ESA}^{+}$cells, which suggests that hedgehog signaling ligand is significantly expressed in pancreatic CSCs [93].

\section{The relationship between EMT and PCSCs}

Of fundamental importance biologically, the activation of EMT process has been associated with the properties of stem cell traits for both normal and neoplastic cells $[18,19]$. The biologic link between EMT phenotypes and CSCs has recently been studied in many types of cancer including PC (Table 1) [52, 94-99]. Cells with an EMT phenotype effect molecular characteristics of CSCs; CSCs also express an EMT phenotype. This phenomenon indicated that EMT and CSCs are closely related [100-102]. In breast cancer, Mani and colleagues reported that the overexpression of Twist, Snail or FOXC2 not only made the breast cancer cells with more mesenchymal properties, but also with an increased expression of $\mathrm{CD} 44^{+} / \mathrm{CD} 24^{- \text {low }}$ breast CSC markers and an increased mammosphere forming efficiency $[18,103]$. The similar results also showed in prostate cancer. Prostate cancer cells with an EMT phenotype have increased expression of Sox2, Nanog, Pou5F1, lin28B and/or Notch1 and an enhanced sphere-forming ability [104].

ZEB1 (zinc finger E-box binding homeobox 1) is a crucial promoter of EMT. ZEB1 can repress the expression of the miR-200 family and stemness-inhibiting miR-203, resulting in activation of EMT and tumor-initiating capacity in pancreatic cancer [96]. In addition, miR-200 family can suppress the expression of stem cell factors, such as Sox2 and Klf4. It is also suggested that ZEB1and PCSCs marker CD44 regulate each other. ZEB1 enforces CD44 isoforms (CD44s) splicing by repression of epithelial splicing regulator ESRP1 in pancreatic cancer. CD44s, in turn, increases the expression of ZEB1, resulting in a self-sustaining ZEB1 and CD44s expression. The relationship of this novel CD44s-ZEB1 impacts on cancer cell ability, including increased tumorsphere initiation capacity and tumor metastasis [105]. These results suggested that ZEB1 linked EMT and stemnessmaintenance in PC.

Nestin was first recognized as a functional stem cell marker in embryonic and adult central nervous system (CNS) stem cells [106]. In addition, recent studies have identified nestin as a CSC marker in brain tumors, ovarian, head and neck, prostate, and PC [107-111]. Compared with parental cells, PC cells with Nestin

Table 1 Principal data regarding the relationship of EMT with PCSCS

\begin{tabular}{|c|c|c|}
\hline Experimental approach & Molecular characteristics of PCSCs & References \\
\hline $\begin{array}{l}\text { Short hairpin RNA (shRNA)-mediated ZEB1-knockdown in } \\
\text { the two cells with the highest levels of ZEB1(Panc-1 and } \\
\text { MiaPaCa-2) }\end{array}$ & $\begin{array}{l}\text { Reduction of CD24+/CD44+ subpopulation, reduced sphere formation } \\
\text { in the two cancer cell lines and sphere numbers in subsequent } \\
\text { generations decreased expression of stem cell factors such as Sox2, } \\
\text { Bmi1 and p63 }\end{array}$ & {$[96]$} \\
\hline CD133 overexpression in Mia PaCa-2 cell & $\begin{array}{l}\text { Increased mRNA expression of several EMT-associated genes: } \\
\text { SNAI1, ZEB1, Vimentin, CDH2 and MMP9. CD133hi-MIA cells show a } \\
\text { more fibroblast-like morphology }\end{array}$ & {$[97]$} \\
\hline Silenced Snail in Panc-1 cells & $\begin{array}{l}\text { A significant decrease in the ALDH }{ }^{\text {high }} \text { population, reduction initial } \\
\text { formation of spheres and sphere numbers in subsequent generations. }\end{array}$ & {$[98]$} \\
\hline $\begin{array}{l}\text { Nestin shRNA in PANC-1 cell and nestin-overexpressing in } \\
\text { MiaPaCa-2 cell }\end{array}$ & $\begin{array}{l}\text { Expression of mesenchymal markers, acquisition of invasive properties } \\
\text { and high motility/opposite effects }\end{array}$ & [99] \\
\hline $\begin{array}{l}\text { Isolate the SP cell fraction (side population, a cancer stem } \\
\text { cell enriched fraction from Panc-1,KP-1NL and Capan-2 } \\
\text { cell lines), incubate SP cells in the presence of TGF- } \beta\end{array}$ & $\begin{array}{l}\text { Production of cells with mesenchymal-like morphology,alteration such } \\
\text { as reduction of E- cadherin mRNA and induction of Snail mRNA and } \\
(\mathrm{MMP})-2 \text { mRNA }\end{array}$ & {$[52]$} \\
\hline
\end{tabular}


knockdown exhibited decreased sphere formation and regulated EMT by decreasing slug expression [112]. Overexpression of nestin induced TGF- $\beta 1$ and the expression of its receptors through the Smad4-dependent pathway in PC and nestin overexpression induces the EMT of PDAC cells. Meanwhile the excessive TGF- $\beta 1$ cytokine as a major EMT-inducing soluble factor results in increased nestin expression. Thus, nestin-positive cells apparently use an autocrine positive feedback loop to regulate EMT in PDAC through TGF- $\beta / \mathrm{Smad}$ pathway [99]. In addition, Hypoxia induction increased expression of the PCSCs markers Notch1, Notch4, c-Met, CD133 and the embryonic stem cell markers Nanog, SOX2, FOXA2, SOX17 and PDX-1 [113]. Among above markers, the upregulation of FOXA2 was accompanied by an EMT, with downregulation of E-cadherin and upregulation of mesenchyme markers Vimentin, Slug, Snail and Twist2. Previous experience in breast cancer showed that Twist2 overexpression not only promoted EMT signaling, but also enhanced colony-forming abilities of stem cells, which suggested that Twist2 may be a master inducer of both EMT and CSC features.

\section{PCSCs, EMT and treatment resistance}

In the clinic, the combination of radio- and chemotherapy with or without surgical intervention is the standard of care in many cancers. Although technical advances in radiation and chemotherapy have improved local control and patient survival. Cancer treatment resistance, including chemoresistance and radioresistance, is still a major challenge in cancer research and treatment $[114,115]$. Treatment resistance has become a key obstacle in improving the effectiveness of tumor therapy, resulting in the high mortality in patients diagnosed with PC. This disappointing situation strongly needs to improve on understanding the mechanisms of the treatment resistance, leading to find out novel therapeutic strategies for overcoming the resistance and increasing the survival rate. Potential mechanisms of resistance to antiangiogenic therapy may result from the selection effect directly and indirectly on advantaged subpopulations of tumor and tumor- associated cells [116].

Accumulating researches clearly suggest that CSCs and EMT-type cells play important roles in chemoresistance and radioresistance (Table 2) [117-122]. The role of CSCs contributing to treatment resistance has been reported to be closely related with activation of the DNA damage checkpoint repair, thereby protecting cells from DNA damage and activating the cell survival signaling pathways $[114,115,123]$. Few of the current therapies can eliminate CSCs because they have critical roles in treatment resistance, which might interpret why cancer is difficultly eradicated completely.
In hematopoietic malignancies, Michor and colleagues identified that a subpopulation of human leukemia stem cells showed resistant to the Abl tyrosine kinase inhibitor imatinib, an effective drug against differentiated leukemic cells. The survived leukemic stem cells regenerated the tumor, providing further evidence supporting the important role of CSCs in tumor relapse [124]. Evidence of the breast CSCs resistance is supported by a study in which tumor biopsies taken from patients with breast cancer during the 12-week chemotherapy treatment conducted increased CSC markers $\left(\mathrm{CD} 44^{+} / \mathrm{CD} 24^{-/ \text {low }}\right.$ and MFSE) [125]. The glioblastoma CSCs were also shown to be responsible to standard therapies resistance in brain tumor. It was identified that the CSC population expressing CD 133 was increased two to four folds in both primary tumors and xenografts after radiation, maybe due to a preferential activation of the DNA damage response [126].

Recently, some studies suggest that pancreatic CSCs may also be resistant to chemotherapy and radiation therapy. With regard to this, Hermann et al. have conducted that human $\mathrm{CD}_{133^{+}}$pancreatic CSCs isolated from pancreatic tumor are highly resistant to standard gemcitabine therapy, which is conventional chemotherapeutic agent against PC [14]. Gemcitabine-resistant cells, which have stronger sphere-forming ability and are more tumorigenic than gemcitabine-sensitive cells in vitro and vivo, were equipped with the similar properties as pancreatic CSCs [127]. Furthermore, it is reported that although the cytotoxic agent gemcitabine can arrest proliferating of CD133 CSCs, the apoptosis of CSCs was not affected, leading to CSCs` returning to stem cell pool when gemcitabine withdrawn. On the contrary, the more differentiated cells $\left(\mathrm{CD} 133^{-}\right)$, the vast majority of the tumour cell, became apoptotic under the management of gemcitabine. It is obvious that only the more differentiated tumour cells can be targeted with standard therapy, leaving undifferentiated cancer stem cells resistant to therapy. These results suggest that therapeutic targeting of the activation of apoptosis might provide a tool to sensitize CSCs to therapy.

Tumor-infiltrating immune cells are feature of most solid tumors, can promote chemoresistance and metastasis in aggressive tumors, leading to awful clinical outcomes of cancer patients $[6,128]$. It has been illustrated that tumor-infiltrating macrophages (TAMs) can directly induce PCSCs properties through the activation of STAT3 pathway. Conversely, STAT3 ${ }^{+}$CSCs enhance TAM-mediated immunosuppression. Furthermore, targeting TAMs by inhibiting either CSF1 receptor (CSF1R) or chemokine (C-C motif) receptor 2 (CCR2) decreases the numbers of pancreatic CSCs and improves chemotherapeutic efficacy in vivo. The PCSCs response 
Table 2 Principal data regarding the role of PCSCs in the induction of treatment resistance

\begin{tabular}{|c|c|c|}
\hline Experimental approach & Molecular characteristics of PCSCs & References \\
\hline $\begin{array}{l}\text { Isolated SP(side population) cell fractions in } \\
\text { L3.6pl cell, gemcitabine- and 5-FU-resistant } \\
\text { L3.6pl cells were established }\end{array}$ & $\begin{array}{l}\text { Induce faster and more aggressive orthotopic tumor growth } \\
\text { with higher rates of metastases, gemcitabine resulted in an } \\
\text { increase of CD24 positive cells and the percentage of SP cells }\end{array}$ & [117] \\
\hline $\begin{array}{l}\text { Incubated in the presence of } 5 \text { - fluorouracil } \\
\text { (5-FU) for } 24 \mathrm{~h} \text {, and further incubated without } \\
5-\mathrm{FU} \text { for } 28 \text { days to eliminate } 5 \text {-FU-sensitive cells. }\end{array}$ & $\begin{array}{l}\text { Certain stemness-genes such as OCT4 and NANOG were } \\
\text { enhanced and spheres arose }\end{array}$ & [118] \\
\hline $\begin{array}{l}\text { Treat Capan-1 and Panc- } 1 \text { cells with serial concentrations } \\
\text { of gemcitabine and counting surviving cells after } 6 \text { days, }\end{array}$ & Stem markers CD44,CD24,CD133,EpCAM,Oct4 and PDX1 increased & [119] \\
\hline $\begin{array}{l}\text { Xenograft tumours were dissociated into single cells and } \\
\text { identified SP cells using FACS analysis }\end{array}$ & $\begin{array}{l}\text { SP displayed higher sphere-forming capacity, epithelial-mesenchymal } \\
\text { transition and gemcitabine reisistant }\end{array}$ & [120] \\
\hline Konckdown of ALDH1 in MIA PaCa-2 cell & $\begin{array}{l}\text { The IC50 of gemcitabine decreased, induction of apoptosis and } \\
\text { S-phase arrest by gemcitabine. }\end{array}$ & [121] \\
\hline $\begin{array}{l}\text { Enriched pancreatic cancer stem CD } 44+/ C D 24+\text { cells in } \\
\text { PANC-1 cells under sphere forming conditions }\end{array}$ & $\begin{array}{l}\text { Increased resistance to gemcitabine, migration ability, exhibit } \\
\text { Epithelial to Mesenchymal Transition (EMT) }\end{array}$ & [122] \\
\hline
\end{tabular}

efficiency to chemotherapeutic is highly related with TAMs [129].

The self-renewal potential and resistance to traditional treatment suggest that maybe strategies targeting CSC will improve clinical outcomes. At first, surface proteins used to enrich for pancreatic CSCs maybe good targets for treatment of pancreatic CSCs. For example, inhibiting c-Met with XL18427 or Alk-4 and -7 with SB431542 can eliminate the CSCs in tumors and enhance the antitumor effect of gemcitabine, reducing tumor burden in mice [90]. In addition to reagents targeting surface proteins of PCSCs, several cellular signaling pathways regulating the self-renewal and proliferation ability of PCSCs may be a potential targets against CSCs. Feldmann and colleagues showed that inhibition of Hedgehog pathway reduces a process of PC metastases, which has been linked to the invasion of CSCs [130]. However, Mueller et al. have shown that neither hh inhibition alone nor rapamycin alone or as supplements to chemotherapy can effectively diminish the CSC pool [131]. Chemotherapy, only with the combined inhibition of hh and mTOR (mammalian target of rapamycin) pathway played a role in reducing the number of CSCs to virtually undetectable levels in vitro and in vivo and significantly prolonged survival of mice. However, CD24, CD44, ESA, CD133 and CXCR4 are also expressed on normal stem cells, which share many pathways with CSCs. Consequently, these reagents might lack important specificity in targeting CSCs. It is important to find out effective targeting strategies achieving the aim of tackling CSCs without harming normal stem cells. Besides, the enrichment of the $\mathrm{CD} 44^{+} \mathrm{CD} 24^{+} \mathrm{ESA}^{+}$cells was observed after the ionizing radiation treatment in human primary pancreatic cancer xenografts. CD44 is required for post-radiation recurrence of xenograft tumors in mice. Antibody against CD44 eliminated bulk tumor cells as well as TICs from the tumors. Strategies to target CD44 might be developed to block postradiotherapy recurrence in patients [132].

\section{Conclusion}

Since cancers are heterogeneous, future novel treatment targets aimed at increasing patient survival will undoubtedly need to consider the heterogeneity of cancer cells. Heterogeneity among cancer cells within the same tumor arises from a consequence of environmental differences, genetic mutation, and reversible changes in cellular properties. Among them one origin of such heterogeneity is EMT and the existence of dedifferentiated cells with CSC-like properties. A better understanding of the properties of EMT and CSCs in PC will play an important role in developing emerging and effective therapies targeting not only the bulk tumor but also the residual cluster of cells that are responsible for the relapse, metastasis and treatment resistance of the tumor. CSC properties have been put forward to explain diverse unsolved clinical problems. However, difficulties confirming solid CSC markers in order to isolate PCSCs have hindered the research identifying their existence in some cancers and studying their biology in clinical applications.

It is now widely accepted that the presence of EMT and a PC subpopulation, with stem cell properties, play important roles in escaping from current clinical specific therapies. In this review we have discussed the detailed process and complex molecular signaling pathways controlling EMT and CSCs in PC during tumor formation, progression, and response to therapy. The combined use of different gene products altered in EMT and PCSCs may represent potential strategies for improving the effectiveness of the diagnostic/prognostic methods and treatments efficacy for cancer patients in the clinics. Targeting CSCs via modification of the Wnt, $\mathrm{HH}$ and Notch signaling pathways of these cells holds the promise of preventing treatment resistance. However, additional 
studies are required to further confirm stem-cells markers and abnormal signaling pathways in CSCs, which have significant correlation with the high treatment resistance of PC.

\section{Acknowledgments}

This work was supported by National Natural Science Foundation of China (grants 81370600), The Program for Professor of Special Appointment (Eastern Scholar) at Shanghai Institutions of Higher Learning(TP2015022)and Shanghai Pujiang Program (15PJ1404800).

\section{Availability of data and materials}

All the authors confirm the availability of data and materials.

\section{Authors' contributions}

LD and ZPT provided direction and guidance throughout the preparation of this manuscript. ZPT and LB conducted the literature review and drafted the manuscript. LFR, ZMC, WQ, LYH, YY reviewed the manuscript and made significant revisions on the drafts. All authors read and approved the final manuscript.

\section{Competing interests}

The authors declare that they have no competing interests.

\section{Consent for publication}

All the authors confirm that the manuscript represents our honest work, and agree to consent for publication in Molecular Cancer.

\section{Ethics approval and consent to participate}

Not applicable.

\section{Author details}

'Department of Oncology, Shanghai Ninth People's Hospital, Shanghai Jiaotong University School of Medicine, Shanghai, China. ${ }^{2}$ Department of Bone Tumor Surgery, Changzheng Hospital, Second Military Medical University, Shanghai, China. ${ }^{3}$ Department of Chemotherapy, Nanjing Medical University Affiliated Cancer Hospital, Cancer Institute of Jiangsu Province, Nanjing, Jiangsu, China. ${ }^{4}$ Department of Radiation Oncology, Shanghai Ninth People's Hospital, Shanghai Jiaotong University School of Medicine, Shanghai, China.

\section{Received: 16 December 2016 Accepted: 23 February 2017}

Published online: 28 February 2017

\section{References}

1. Jemal A, Bray F, Center MM, Ferlay J, Ward E, Forman D. Global cancer statistics. CA Cancer J Clin. 2011:61:69-90.

2. Krejs GJ. Pancreatic cancer: epidemiology and risk factors. Dig Dis. 2010;28: 355-8.

3. Crist DW, Sitzmann JV, Cameron JL. Improved hospital morbidity, mortality and survival after the Whipple procedure. Ann Surg. 1987;206:358-65.

4. Geer RJ, Brennan MF. Prognostic indicators for survival after resection of pancreatic adenocarcinoma. Am J Surg. 1993;165:68-72. discussion 72-63.

5. Trede M, Schwall G, Saeger HD. Survival after pancreatoduodenectomy. 118 consecutive resections without an operative mortality. Ann Surg. 1990;211: 447-58.

6. Hanahan D, Weinberg RA. Hallmarks of cancer: the next generation. Cell. 2011:144:646-74.

7. O'Connor ML, Xiang D, Shigdar S, Macdonald J, Li Y, Wang T, Pu C, Wang Z, Qiao L, Duan W. Cancer stem cells: A contentious hypothesis now moving forward. Cancer Lett. 2014;344:180-7.

8. Bonnet D, Dick JE. Human acute myeloid leukemia is organized as a hierarchy that originates from a primitive hematopoietic cell. Nat Med. 1997:3:730-7.

9. Gratwohl A, Brand R, Apperley J, Biezen Av A, Bandini G, Devergie A Schattenberg A, Frassoni F, Guglielmi C, lacobelli S, et al. Graft-versus-host disease and outcome in HLA-identical sibling transplantations for chronic myeloid leukemia. Blood. 2002;100:3877-86.

10. Orkin SH, Zon LI. Hematopoiesis: an evolving paradigm for stem cell biology. Cell. 2008;132:631-44.
11. Al-Hajj M, Wicha MS, Benito-Hernandez A, Morrison SJ, Clarke MF. Prospective identification of tumorigenic breast cancer cells. Proc Nat Acad Sci U S A. 2003;100:3983-8.

12. Singh SK, Clarke ID, Terasaki M, Bonn VE, Hawkins C, Squire J, Dirks PB. Identification of a cancer stem cell in human brain tumors. Cancer Res. 2003:63:5821-8

13. Li C, Heidt DG, Dalerba P, Burant CF, Zhang L, Adsay V, Wicha M, Clarke MF, Simeone DM. Identification of pancreatic cancer stem cells. Cancer Res. 2007:67:1030-7.

14. Hermann PC, Huber SL, Herrler T, Aicher A, Ellwart JW, Guba M, Bruns CJ, Heeschen C. Distinct populations of cancer stem cells determine tumor growth and metastatic activity in human pancreatic cancer. Cell Stem Cell. 2007:1:313-23.

15. Frank NY, Margaryan A, Huang Y, Schatton T, Waaga-Gasser AM, Gasser M Sayegh MH, Sadee W, Frank MH. ABCB5-mediated doxorubicin transport and chemoresistance in human malignant melanoma. Cancer Res. 2005;65: 4320-33.

16. Miki J, Furusato B, Li H, Gu Y, Takahashi H, Egawa S, Sesterhenn IA, McLeod DG, Srivastava S, Rhim JS. Identification of putative stem cell markers, CD133 and CXCR4, in hTERT-immortalized primary nonmalignant and malignant tumor-derived human prostate epithelial cell lines and in prostate cancer specimens. Cancer Res. 2007;67:3153-61.

17. O'Brien CA, Pollett A, Gallinger S, Dick JE. A human colon cancer cell capable of initiating tumour growth in immunodeficient mice. Nature. 2007; 445:106-10.

18. Mani SA, Guo W, Liao MJ, Eaton EN, Ayyanan A, Zhou AY, Brooks M, Reinhard F, Zhang CC, Shipitsin M, et al. The epithelial-mesenchymal transition generates cells with properties of stem cells. Cell. 2008;133: 704-15

19. Morel AP, Lievre M, Thomas C, Hinkal G, Ansieau S, Puisieux A. Generation of breast cancer stem cells through epithelial-mesenchymal transition. PLoS One. 2008:3:e2888.

20. Kalluri R, Neilson EG. Epithelial-mesenchymal transition and its implications for fibrosis. J Clin Invest. 2003:112:1776-84.

21. Thiery JP, Sleeman JP. Complex networks orchestrate epithelialmesenchymal transitions. Nat Rev Mol Cell Biol. 2006;7:131-42.

22. Kalluri R, Zeisberg M. Fibroblasts in cancer. Nat Rev Cancer. 2006;6:392-401.

23. Kalluri R, Weinberg RA. The basics of epithelial-mesenchymal transition. J Clin Invest. 2009:119:1420-8.

24. Hugo H, Ackland ML, Blick T, Lawrence MG, Clements JA, Williams ED, Thompson EW. Epithelial-mesenchymal and mesenchymal-epithelial transitions in carcinoma progression. J Cell Physiol. 2007;213:374-83.

25. Valastyan S, Weinberg RA. Tumor metastasis: molecular insights and evolving paradigms. Cell. 2011;147:275-92.

26. Thiery JP, Acloque H, Huang RY, Nieto MA. Epithelial-mesenchymal transitions in development and disease. Cell. 2009;139:871-90.

27. Acloque $\mathrm{H}$, Adams MS, Fishwick K, Bronner-Fraser M, Nieto MA. Epithelialmesenchymal transitions: the importance of changing cell state in development and disease. J Clin Invest. 2009:119:1438-49.

28. Hay ED. An overview of epithelio-mesenchymal transformation. Acta Anat (Basel). 1995:154:8-20.

29. Chu YS, Eder O, Thomas WA, Simcha I, Pincet F, Ben-Ze'ev A, Perez E, Thiery JP, Dufour S. Prototypical type I E-cadherin and type || cadherin-7 mediate very distinct adhesiveness through their extracellular domains. J Biol Chem. 2006;281:2901-10

30. Halbleib JM, Nelson WJ. Cadherins in development: cell adhesion, sorting, and tissue morphogenesis. Genes Dev. 2006:20:3199-214.

31. Nieto MA, Cano A. The epithelial-mesenchymal transition under control: global programs to regulate epithelial plasticity. Semin Cancer Biol. 2012;22: 361-8.

32. Tiwari N, Tiwari VK, Waldmeier L, Balwierz PJ, Arnold P, Pachkov M, Meyer-Schaller N, Schubeler D, van Nimwegen E, Christofori G. Sox4 is a master regulator of epithelial-mesenchymal transition by controlling Ezh2 expression and epigenetic reprogramming. Cancer Cell. 2013;23: $768-83$

33. Guo W, Keckesova Z, Donaher JL, Shibue T, Tischler V, Reinhardt F, Itzkovitz S, Noske A, Zurrer-Hardi U, Bell G, et al. Slug and Sox9 cooperatively determine the mammary stem cell state. Cell. 2012:148:1015-28.

34. Tiwari N, Meyer-Schaller N, Arnold P, Antoniadis H, Pachkov M, van

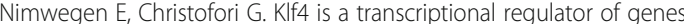
critical for EMT, including Jnk1 (Mapk8). PLoS One. 2013;8:e57329. 
35. Bakiri L, Macho-Maschler S, Custic I, Niemiec J, Guio-Carrion A, Hasenfuss SC, Eger A, Muller M, Beug H, Wagner EF. Fra-1/AP-1 induces EMT in mammary epithelial cells by modulating Zeb1/2 and TGFbeta expression. Cell Death Differ. 2015;22:336-50.

36. Nieto MA. The ins and outs of the epithelial to mesenchymal transition in health and disease. Annu Rev Cell Dev Biol. 2011;27:347-76.

37. Ansieau S, Bastid J, Doreau A, Morel AP, Bouchet BP, Thomas C, Fauvet F, Puisieux I, Doglioni C, Piccinin S, et al. Induction of EMT by twist proteins as a collateral effect of tumor-promoting inactivation of premature senescence. Cancer Cell. 2008:14:79-89.

38. Mejlvang J, Kriajevska M, Vandewalle C, Chernova T, Sayan AE, Berx G, Mellon JK, Tulchinsky E. Direct repression of cyclin D1 by SIP1 attenuates cell cycle progression in cells undergoing an epithelial mesenchymal transition. Mol Biol Cell. 2007;18:4615-24.

39. Birchmeier W, Behrens J. Cadherin expression in carcinomas: role in the formation of cell junctions and the prevention of invasiveness. Biochim Biophys Acta. 1994;1198:11-26.

40. Perez-Moreno MA, Locascio A, Rodrigo I, Dhondt G, Portillo F, Nieto MA, Cano A. A new role for E12/E47 in the repression of E-cadherin expression and epithelial-mesenchymal transitions. J Biol Chem. 2001; 276:27424-31.

41. Peinado H, Olmeda D, Cano A. Snail, Zeb and bHLH factors in tumour progression: an alliance against the epithelial phenotype? Nat Rev Cancer. 2007;7:415-28.

42. Yang MH, Wu KJ. TWIST activation by hypoxia inducible factor-1 (HIF-1): implications in metastasis and development. Cell Cycle. 2008;7:2090-6.

43. Peinado H, Portillo F, Cano A. Transcriptional regulation of cadherins during development and carcinogenesis. Int J Dev Biol. 2004;48:365-75.

44. Onder TT, Gupta PB, Mani SA, Yang J, Lander ES, Weinberg RA. Loss of E-cadherin promotes metastasis via multiple downstream transcriptional pathways. Cancer Res. 2008;68:3645-54.

45. Massague J. How cells read TGF-beta signals. Nat Rev Mol Cell Biol. 2000;1: $169-78$

46. Heldin $\mathrm{CH}$, Moustakas A. Role of Smads in TGFbeta signaling. Cell Tissue Res. 2012;347:21-36.

47. Valcourt U, Kowanetz M, Niimi H, Heldin CH, Moustakas A. TGF-beta and the Smad signaling pathway support transcriptomic reprogramming during epithelial-mesenchymal cell transition. Mol Biol Cell. 2005;16:1987-2002.

48. Derynck R, Zhang YE. Smad-dependent and Smad-independent pathways in TGF-beta family signalling. Nature. 2003;425:577-84.

49. Conery AR, Cao Y, Thompson EA, Townsend Jr CM, Ko TC, Luo K. Akt interacts directly with Smad3 to regulate the sensitivity to TGF-beta induced apoptosis. Nat Cell Biol. 2004;6:366-72.

50. Sano Y, Harada J, Tashiro S, Gotoh-Mandeville R, Maekawa T, Ishii S. ATF-2 is a common nuclear target of Smad and TAK1 pathways in transforming growth factor-beta signaling. J Biol Chem. 1999;274:8949-57.

51. Gulhati P, Bowen KA, Liu J, Stevens PD, Rychahou PG, Chen M, Lee EY, Weiss HL, O'Connor KL, Gao T, Evers BM. mTORC1 and mTORC2 regulate EMT, motility, and metastasis of colorectal cancer via RhoA and Rac1 signaling pathways. Cancer Res. 2011;71:3246-56.

52. Kabashima A, Higuchi H, Takaishi H, Matsuzaki Y, Suzuki S, Izumiya M, lizuka H, Sakai G, Hozawa S, Azuma T, Hibi T. Side population of pancreatic cancer cells predominates in TGF-beta-mediated epithelial to mesenchymal transition and invasion. Int J Cancer. 2009:124:2771-9.

53. Lamouille S, Connolly E, Smyth JW, Akhurst RJ, Derynck R. TGF-beta-induced activation of mTOR complex 2 drives epithelial-mesenchymal transition and cell invasion. J Cell Sci. 2012;125:1259-73.

54. Mimeault M, Batra SK. Interplay of distinct growth factors during epithelial mesenchymal transition of cancer progenitor cells and molecular targeting as novel cancer therapies. Ann Oncol. 2007;18:1605-19.

55. Mimeault M, Batra SK. New advances on critical implications of tumor- and metastasis-initiating cells in cancer progression, treatment resistance and disease recurrence. Histol Histopathol. 2010;25:1057-73.

56. van den Hoogen C, van der Horst G, Cheung H, Buijs JT, Pelger RC van der Pluijm G. The aldehyde dehydrogenase enzyme 7A1 is functionally involved in prostate cancer bone metastasis. Clin Exp Metastasis. 2011;28:615-25.

57. Wang L, Mezencev R, Bowen NJ, Matyunina LV, McDonald JF. Isolation and characterization of stem-like cells from a human ovarian cancer cell line. Mol Cell Biochem. 2012;363:257-68
58. Wang H, Wu J, Zhang Y, Xue X, Tang D, Yuan Z, Chen M, Wei J, Zhang J, Miao Y. Transforming growth factor beta-induced epithelial-mesenchymal transition increases cancer stem-like cells in the PANC-1 cell line. Oncol Lett. 2012;3:229-33.

59. Wu CY, Tsai YP, Wu MZ, Teng SC, Wu KJ. Epigenetic reprogramming and post-transcriptional regulation during the epithelial-mesenchymal transition. Trends Genet. 2012;28:454-63.

60. De Craene B, Berx G. Regulatory networks defining EMT during cancer initiation and progression. Nat Rev Cancer. 2013;13:97-110.

61. Zhang J, Ma L. MicroRNA control of epithelial-mesenchymal transition and metastasis. Cancer Metastasis Rev. 2012:31:653-62.

62. Korpal M, Lee ES, Hu G, Kang Y. The miR-200 family inhibits epithelialmesenchymal transition and cancer cell migration by direct targeting of E-cadherin transcriptional repressors ZEB1 and ZEB2. J Biol Chem. 2008;283: 14910-4.

63. Gregory PA, Bert AG, Paterson EL, Barry SC, Tsykin A, Farshid G, Vadas MA, Khew-Goodall Y, Goodall GJ. The miR-200 family and miR-205 regulate epithelial to mesenchymal transition by targeting ZEB1 and SIP1. Nat Cell Biol. 2008;10:593-601.

64. Burk U, Schubert J, Wellner U, Schmalhofer O, Vincan E, Spaderna S, Brabletz $T$. A reciprocal repression between ZEB1 and members of the miR-200 family promotes EMT and invasion in cancer cells. EMBO Rep. 2008:9:582-9.

65. Bracken CP, Gregory PA, Kolesnikoff N, Bert AG, Wang J, Shannon MF, Goodall GJ. A double-negative feedback loop between ZEB1-SIP1 and the microRNA-200 family regulates epithelial-mesenchymal transition. Cancer Res. 2008;68:7846-54.

66. Park SM, Gaur AB, Lengyel E, Peter ME. The miR-200 family determines the epithelial phenotype of cancer cells by targeting the E-cadherin repressors ZEB1 and ZEB2. Genes Dev. 2008:22:894-907.

67. Huang Q, Gumireddy K, Schrier M, le Sage C, Nagel R, Nair S, Egan DA, Li A, Huang G, Klein-Szanto AJ, et al. The microRNAs miR-373 and miR-520c promote tumour invasion and metastasis. Nat Cell Biol. 2008;10:202-10.

68. Ma L, Teruya-Feldstein J, Weinberg RA. Tumour invasion and metastasis initiated by microRNA-10b in breast cancer. Nature. 2007;449:682-8.

69. Zavadil J, Narasimhan M, Blumenberg M, Schneider RJ. Transforming growth factor-beta and microRNA:mRNA regulatory networks in epithelial plasticity. Cells Tissues Organs. 2007:185:157-61.

70. Hill RP, Perris R. "Destemming" cancer stem cells. J Natl Cancer Inst. 2007;99: 1435-40.

71. Clarke MF, Dick JE, Dirks PB, Eaves CJ, Jamieson CH, Jones DL, Visvader J, Weissman IL, Wahl GM. Cancer stem cells-perspectives on current status and future directions: AACR Workshop on cancer stem cells. Cancer Res. 2006;66:9339-44.

72. Huntly BJ, Shigematsu H, Deguchi K, Lee BH, Mizuno S, Duclos N, Rowan R, Amaral S, Curley D, Williams IR, et al. MOZ-TIF2, but not BCR-ABL, confers properties of leukemic stem cells to committed murine hematopoietic progenitors. Cancer Cell. 2004;6:587-96.

73. Jamieson CH, Ailles LE, Dylla SJ, Muijtiens M, Jones C, Zehnder JL, Gotlib J, Li K, Manz MG, Keating A, et al. Granulocyte-macrophage progenitors as candidate leukemic stem cells in blast-crisis CML. N Engl J Med. 2004;351: 657-67.

74. Li L, Neaves WB. Normal stem cells and cancer stem cells: the niche matters. Cancer Res. 2006;66:4553-7.

75. Muller A, Homey B, Soto H, Ge N, Catron D, Buchanan ME, McClanahan T, Murphy E, Yuan W, Wagner SN, et al. Involvement of chemokine receptors in breast cancer metastasis. Nature. 2001:410:50-6.

76. Li C, Wu JJ, Hynes M, Dosch J, Sarkar B, Welling TH, Pasca di Magliano M, Simeone DM. c-Met is a marker of pancreatic cancer stem cells and therapeutic target. Gastroenterology. 2011;141:2218-27. e2215.

77. Birchmeier C, Gherardi E. Developmental roles of HGF/SF and its receptor, the c-Met tyrosine kinase. Trends Cell Biol. 1998;8:404-10.

78. Gherardi E, Birchmeier W, Birchmeier C, Vande Woude G. Targeting MET in cancer: rationale and progress. Nat Rev Cancer. 2012;12:89-103.

79. Corso S, Comoglio PM, Giordano S. Cancer therapy: can the challenge be MET? Trends Mol Med. 2005;11:284-92.

80. Bailey JM, Alsina J, Rasheed ZA, McAllister FM, Fu YY, Plentz R, Zhang H, Pasricha PJ, Bardeesy N, Matsui W, et al. DCLK1 marks a morphologically distinct subpopulation of cells with stem cell properties in preinvasive pancreatic cancer. Gastroenterology. 2014;146:245-56. 
81. Apelqvist A, Li H, Sommer L, Beatus P, Anderson DJ, Honjo T, Hrabe de Angelis $\mathrm{M}$, Lendahl $\mathrm{U}$, Edlund $\mathrm{H}$. Notch signalling controls pancreatic cell differentiation. Nature. 1999;400:877-81.

82. Miralles F, Lamotte L, Couton D, Joshi RL. Interplay between FGF10 and Notch signalling is required for the self-renewal of pancreatic progenitors. Int J Dev Biol. 2006;50:17-26.

83. Murtaugh LC, Stanger BZ, Kwan KM, Melton DA. Notch signaling controls multiple steps of pancreatic differentiation. Proc Natl Acad Sci U S A. 2003; 100:14920-5.

84. Wang J, Sullenger BA, Rich JN. Notch signaling in cancer stem cells. Adv Exp Med Biol. 2012;727:174-85.

85. Brabletz S, Bajdak K, Meidhof S, Burk U, Niedermann G, Firat E, Wellner U, Dimmler A, Faller G, Schubert J, Brabletz T. The ZEB1/miR-200 feedback loop controls Notch signalling in cancer cells. EMBO J. 2011;30:770-82.

86. Mizuma M, Rasheed ZA, Yabuuchi S, Omura N, Campbell NR, de Wilde RF, De Oliveira E, Zhang Q, Puig O, Matsui W, et al. The gamma secretase inhibitor MRK-003 attenuates pancreatic cancer growth in preclinical models. Mol Cancer Ther. 2012;11:1999-2009.

87. Hald J, Hjorth JP, German MS, Madsen OD, Serup P, Jensen J. Activated Notch1 prevents differentiation of pancreatic acinar cells and attenuate endocrine development. Dev Biol. 2003;260:426-37.

88. Vallier L, Alexander M, Pedersen RA. Activin/Nodal and FGF pathways cooperate to maintain pluripotency of human embryonic stem cells. J Cell Sci. 2005;118:4495-509.

89. Xiao L, Yuan X, Sharkis SJ. Activin A maintains self-renewal and regulates fibroblast growth factor, Wnt, and bone morphogenic protein pathways in human embryonic stem cells. Stem Cells. 2006;24:1476-86.

90. Lonardo E, Hermann PC, Mueller MT, Huber S, Balic A, Miranda-Lorenzo I, Zagorac S, Alcala S, Rodriguez-Arabaolaza I, Ramirez JC, et al. Nodal/Activin signaling drives self-renewal and tumorigenicity of pancreatic cancer stem cells and provides a target for combined drug therapy. Cell Stem Cell. 2011; 9:433-46.

91. Bar EE, Chaudhry A, Lin A, Fan X, Schreck K, Matsui W, Piccirillo S, Vescovi AL, DiMeco F, Olivi A, Eberhart CG. Cyclopamine-mediated hedgehog pathway inhibition depletes stem-like cancer cells in glioblastoma. Stem Cells. 2007;25:2524-33.

92. Matsubara S, Ding Q, Miyazaki Y, Kuwahata T, Tsukasa K, Takao S. mTOR plays critical roles in pancreatic cancer stem cells through specific and stemness-related functions. Sci Rep. 2013;3:3230.

93. Lee CJ, Dosch J, Simeone DM. Pancreatic cancer stem cells. J Clin Oncol. 2008;26:2806-12

94. Tam WL, Weinberg RA. The epigenetics of epithelial-mesenchymal plasticity in cancer. Nat Med. 2013;19:1438-49.

95. Dong C, Wu Y, Yao J, Wang Y, Yu Y, Rychahou PG, Evers BM, Zhou BP. G9a interacts with Snail and is critical for Snail-mediated E-cadherin repression in human breast cancer. J Clin Invest. 2012;122:1469-86.

96. Wellner U, Schubert J, Burk UC, Schmalhofer O, Zhu F, Sonntag A, Waldvogel B, Vannier C, Darling D, zur Hausen A, et al. The EMT-activator ZEB1 promotes tumorigenicity by repressing stemness-inhibiting microRNAs. Nat Cell Biol. 2009;11:1487-95.

97. Nomura A, Banerjee S, Chugh R, Dudeja V, Yamamoto M, Vickers SM, Saluja AK. CD133 initiates tumors, induces epithelial-mesenchymal transition and increases metastasis in pancreatic cancer. Oncotarget. 2015;6:8313-22.

98. Zhou W, Lv R, Qi W, Wu D, Xu Y, Liu W, Mou Y, Wang L. Snail contributes to the maintenance of stem cell-like phenotype cells in human pancreatic cancer. PLoS One. 2014;9:e87409.

99. Su HT, Weng CC, Hsiao PJ, Chen LH, Kuo TL, Chen YW, Kuo KK, Cheng KH. Stem cell marker nestin is critical for TGF-beta1-mediated tumor progression in pancreatic cancer. Mol Cancer Res. 2013;11:768-79.

100. Baccelli I, Trumpp A. The evolving concept of cancer and metastasis stem cells. J Cell Biol. 2012;198:281-93.

101. Todaro M, Gaggianesi M, Catalano V, Benfante A, lovino F, Biffoni M, Apuzzo T, Sperduti I, Volpe S, Cocorullo G, et al. CD44v6 is a marker of constitutive and reprogrammed cancer stem cells driving colon cancer metastasis. Cell Stem Cell. 2014;14:342-56.

102. Singh A, Settleman J. EMT, cancer stem cells and drug resistance: an emerging axis of evil in the war on cancer. Oncogene. 2010;29:4741-51.

103. Hollier BG, Tinnirello AA, Werden SJ, Evans KW, Taube JH, Sarkar TR, Sphyris N, Shariati M, Kumar SV, Battula VL, et al. FOXC2 expression links epithelialmesenchymal transition and stem cell properties in breast cancer. Cancer Res. 2013;73:1981-92.
104. Dembinski JL, Krauss S. Characterization and functional analysis of a slow cycling stem cell-like subpopulation in pancreas adenocarcinoma. Clin Exp Metastasis. 2009;26:611-23.

105. Preca BT, Bajdak K, Mock K, Sundararajan V, Pfannstiel J, Maurer J, Wellner U, Hopt UT, Brummer T, Brabletz S, et al. A self-enforcing CD44s/ZEB1 feedback loop maintains EMT and stemness properties in cancer cells. Int J Cancer. 2015;137:2566-77

106. Hendrickson ML, Rao AJ, Demerdash ON, Kalil RE. Expression of nestin by neural cells in the adult rat and human brain. PLoS One. 2011;6:e18535.

107. Ohike N, Sato M, Hisayuki T, Imataka H, Sato S, Wada Y, Saito K, Takahashi M, Tajiri T, Kunimura T, Morohoshi T. Immunohistochemical analysis of nestin and c-kit and their significance in pancreatic tumors. Pathol Int. 2007;57: 589-93.

108. Ishiwata T, Matsuda Y, Naito Z. Nestin in gastrointestinal and other cancers: effects on cells and tumor angiogenesis. World J Gastroenterol. 2011;17: 409-18

109. Gu G, Yuan J, Wills M, Kasper S. Prostate cancer cells with stem cell characteristics reconstitute the original human tumor in vivo. Cancer Res. 2007;67:4807-15.

110. Sato A, Ishiwata T, Matsuda Y, Yamamoto T, Asakura H, Takeshita T, Naito Z. Expression and role of nestin in human cervical intraepithelial neoplasia and cervical cancer. Int J Oncol. 2012;41:441-8.

111. Kawamoto M, Ishiwata T, Cho K, Uchida E, Korc M, Naito Z, Tajiri T. Nestin expression correlates with nerve and retroperitoneal tissue invasion in pancreatic cancer. Hum Pathol. 2009;40:189-98.

112. Matsuda Y, Yoshimura H, Ueda J, Naito Z, Korc M, Ishiwata T. Nestin delineates pancreatic cancer stem cells in metastatic foci of NOD/Shi-scid IL2Rgamma(null) (NOG) mice. Am J Pathol. 2014;184:674-85.

113. Liu L, Salnikov AV, Bauer N, Aleksandrowicz E, Labsch S, Nwaeburu C, Mattern J, Gladkich J, Schemmer P, Werner J, Herr I. Triptolide reverses hypoxia-induced epithelial-mesenchymal transition and stem-like features in pancreatic cancer by NF-kappaB downregulation. Int J Cancer. 2014;134 2489-503.

114. Baumann M, Krause M, Hill R. Exploring the role of cancer stem cells in radioresistance. Nat Rev Cancer. 2008;8:545-54.

115. Holohan C, Van Schaeybroeck S, Longley DB, Johnston PG. Cancer drug resistance: an evolving paradigm. Nat Rev Cancer. 2013;13:714-26.

116. Bottsford-Miller JN, Coleman RL, Sood AK. Resistance and escape from antiangiogenesis therapy: clinical implications and future strategies. J Clin Oncol. 2012:30:4026-34.

117. Niess H, Camaj P, Renner A, Ischenko I, Zhao Y, Krebs S, Mysliwietz J, Jackel C, Nelson PJ, Blum H, et al. Side population cells of pancreatic cancer show characteristics of cancer stem cells responsible for resistance and metastasis. Target Oncol. 2015;10:215-27.

118. Izumiya M, Kabashima A, Higuchi H, Igarashi T, Sakai G, lizuka H, Nakamura S, Adachi M, Hamamoto Y, Funakoshi S, et al. Chemoresistance is associated with cancer stem cell-like properties and epithelial-to-mesenchymal transition in pancreatic cancer cells. Anticancer Res. 2012;32:3847-53.

119. Quint K, Tonigold M, Di Fazio P, Montalbano R, Lingelbach S, Ruckert F, Alinger B, Ocker M, Neureiter D. Pancreatic cancer cells surviving gemcitabine treatment express markers of stem cell differentiation and epithelial-mesenchymal transition. Int J Oncol. 2012;41:2093-102.

120. Van den Broeck A, Gremeaux L, Topal B, Vankelecom H. Human pancreatic adenocarcinoma contains a side population resistant to gemcitabine. BMC Cancer. 2012;12:354.

121. Duong HQ, Hwang JS, Kim HJ, Kang HJ, Seong YS, Bae I. Aldehyde dehydrogenase $1 \mathrm{~A} 1$ confers intrinsic and acquired resistance to gemcitabine in human pancreatic adenocarcinoma MIA PaCa-2 cells. Int J Oncol. 2012;41:855-61.

122. Yin T, Wei H, Gou S, Shi P, Yang Z, Zhao G, Wang C. Cancer stem-like cells enriched in Panc-1 spheres possess increased migration ability and resistance to gemcitabine. Int J Mol Sci. 2011;12:1595-604.

123. Peitzsch C, Kurth I, Kunz-Schughart L, Baumann M, Dubrovska A. Discovery of the cancer stem cell related determinants of radioresistance. Radiother Oncol. 2013;108:378-87.

124. Michor F, Hughes TP, Iwasa Y, Branford S, Shah NP, Sawyers CL, Nowak MA. Dynamics of chronic myeloid leukaemia. Nature. 2005;435:1267-70.

125. Chang JC, Wooten EC, Tsimelzon A, Hilsenbeck SG, Gutierrez MC, Tham YL, Kalidas M, Elledge R, Mohsin S, Osborne CK, et al. Patterns of resistance and incomplete response to docetaxel by gene expression profiling in breast cancer patients. J Clin Oncol. 2005;23:1169-77. 
126. Bao S, Wu Q, McLendon RE, Hao Y, Shi Q, Hjelmeland AB, Dewhirst MW, Bigner DD, Rich JN. Glioma stem cells promote radioresistance by preferential activation of the DNA damage response. Nature. 2006;444: 756-60.

127. Hong SP, Wen J, Bang S, Park S, Song SY. CD44-positive cells are responsible for gemcitabine resistance in pancreatic cancer cells. Int J Cancer. 2009;125: 2323-31.

128. Grivennikov SI, Greten FR, Karin M. Immunity, inflammation, and cancer. Cell. 2010;140:883-99.

129. Mitchem JB, Brennan DJ, Knolhoff BL, Belt BA, Zhu Y, Sanford DE, Belaygorod L, Carpenter D, Collins L, Piwnica-Worms D, et al. Targeting tumor-infiltrating macrophages decreases tumor-initiating cells, relieves immunosuppression, and improves chemotherapeutic responses. Cancer Res. 2013;73:1128-41.

130. Feldmann G, Dhara S, Fendrich V, Bedja D, Beaty R, Mullendore M, Karikari C, Alvarez $\mathrm{H}$, lacobuzio-Donahue C, Jimeno A, et al. Blockade of hedgehog signaling inhibits pancreatic cancer invasion and metastases: a new paradigm for combination therapy in solid cancers. Cancer Res. 2007;67: 2187-96.

131. Mueller MT, Hermann PC, Witthauer J, Rubio-Viqueira B, Leicht SF, Huber S, Ellwart JW, Mustafa M, Bartenstein P, D'Haese JG, et al. Combined targeted treatment to eliminate tumorigenic cancer stem cells in human pancreatic cancer. Gastroenterology. 2009;137:1102-13.

132. Li L, Hao X, Qin J, Tang W, He F, Smith A, Zhang M, Simeone DM, Qiao XT, Chen ZN, et al. Antibody against CD44s inhibits pancreatic tumor initiation and postradiation recurrence in mice. Gastroenterology. 2014;146:1108-18.

\section{Submit your next manuscript to BioMed Central and we will help you at every step:}

- We accept pre-submission inquiries

- Our selector tool helps you to find the most relevant journal

- We provide round the clock customer support

- Convenient online submission

- Thorough peer review

- Inclusion in PubMed and all major indexing services

- Maximum visibility for your research

Submit your manuscript at www.biomedcentral.com/submit

) Biomed Central 